\title{
Tuning Photophysical and Electrochemical Properties of Heteroleptic Cationic Iridium(III) Complexes Containing Substituted 2-Phenylquinoxaline and Biimidazole
}

\author{
Nallathambi Sengottuvelan, Hoe-Joo Seo, ${ }^{\dagger}$ Sung Kwon Kang, ${ }^{\dagger}$ and Young-Inn Kim* \\ Department of Chemistry Education and Interdisciplinary Program of Advanced Information and Display Materials, \\ Pusan National University, Pusan 609-735, Korea. ${ }^{*}$ E-mail: yikim@pusan.ac.kr \\ ${ }^{\dagger}$ Department of Chemistry, Pusan National University, Pusan 609-735, Korea \\ ${ }^{\ddagger}$ Department of Chemistry, Chungnam National University, Daejeon 305-764, Korea \\ Received April 22, 2010, Accepted June 28, 2010
}

\begin{abstract}
Design and syntheses of four red phosphorescent heteroleptic cationic iridium(III) complexes containing two substituted phenylquinoxaline (pqx) or benzo[b]thiophen-2-yl-pyridin (btp) main ligands and one 2,2'-biimidazole $\left(\mathrm{H}_{2}\right.$ biim) ancillary ligand are reported: $\left[(\mathrm{pqx})_{2} \operatorname{Ir}(\mathrm{biim})\right] \mathrm{Cl}(\mathbf{1}),\left[(\mathrm{dmpqx})_{2} \operatorname{Ir}(\right.$ biim $\left.)\right] \mathrm{Cl}(\mathbf{2}),\left[(\mathrm{dfpqx})_{2} \operatorname{Ir}(\operatorname{biim})\right] \mathrm{Cl}(\mathbf{3})$, $\left[(\mathrm{btp})_{2} \operatorname{Ir}(\right.$ biim) $] \mathrm{Cl}(4)$. Complex 1 showed a distorted octahedral geometry around the iridium(III) metal ion with cis metallated carbons and trans nitrogen atoms. The absorption, emission and electrochemical properties were systematically evaluated. The complexes exhibited red phosphorescence in the spectral range of 580 to $620 \mathrm{~nm}$ with high quantum efficiencies of $0.58-0.78$ in both solution and solid-state at room temperature depending on the cyclometalated main ligands. The cyclic voltammetry of the complexes (1-3) showed a metal-centered irreversible oxidation in the range of 1.40 to $1.90 \mathrm{~V}$ as well as two quasi reversible reduction waves from -1.15 to $-1.45 \mathrm{~V}$ attributed to the sequential addition of two electrons to the more electron accepting heterocyclic portion of two distinctive cyclometalated main ligands, whereas complex 4 showed a reversible oxidation potential at $1.24 \mathrm{~V}$ and irreversible reduction waves at $-1.80 \mathrm{~V}$.
\end{abstract}

Key Words: Cationic iridium(III) complex, Luminescence, Red phosphorescence, Color tuning, Electrochemistry

\section{Introduction}

Organometallic heavy metal complexes, particularly iridium (III) complexes have attracted widespread interests due to their applications in organic light-emitting diodes (OLEDs), ${ }^{1}$ chemosensors $^{2}$ and luminescent biological-labeling reagents. ${ }^{3} \mathrm{~A}$ recent trend in OLEDs involves the use of ionic transition metal complexes (iTMCs) as the single-component solid-state electroluminescent layer. ${ }^{4}$ Unlike neutral metal complexes, iTMCs contain mobile counter ions that facilitate charge transport across the film and eliminate the need for electron and holeinjection layers. The iTMCs based single-layer electroluminescent devices may also operate at low voltage with high work function air-stable electrodes and easy to produce. The iTMCs such as $\left[\operatorname{Ru}\left(2,2^{\prime} \text {-bipyridine }\right)_{3}\right]^{2+},\left[\operatorname{Ir}(\text { ppy })_{2}\left(2,2^{\prime} \text {-bipyridine }\right)\right]^{+}$ and $\left[\operatorname{Ir}(\mathrm{ppy})_{2}(4-\mathrm{ph}, 7-\mathrm{ph}-1,-1,10-\text { phen })\right]^{+}$, where ppy $=2$-phenylpridine, based stable single layer light-emitting electrochemical cell have emerged as promising chromophoric materials. ${ }^{5}$ These results promoted us to perform a systematic investigation of new class of red phosphorescent heteroleptic ionic iridium(III) complexes, bearing substituted 2-phenylquinoxaline (pqx) or benzo[b]thiophen-2-yl-pyridine (btp) as cyclometalated main ligands and 2,2'-biimidazole ( $\mathrm{H}_{2}$ biim) as an ancillary ligand. The $\mathrm{H}_{2}$ biim ligand has a bifunctionality: the imino moieties can coordinate with a $\operatorname{Ir}(\mathrm{III})$-pqx fragment and amino groups may donate 2 -fold hydrogen bonding to an anion. The coordinated $\mathrm{H}_{2}$ biim with a metal fragment would (a) enforce the syn conformation and therefore pre-organize $\mathrm{H}_{2}$ biim opti- mally for anion binding receptor, (b) enhance the polarization of the biimidazole N-H bonds, making them better hydrogen bond donors for cationic metal fragments, and (c) phototriggered proton-coupled electron transfer (PCET) from a luminescent excited state. ${ }^{6}$ Furthermore red-emitting iridium complexes, which are important for the realization of RGB full-color displays and the creation of white organic light-emitting devices (WOLEDs), are still scarce. ${ }^{7}$ Here we describe the synthesis, characterization, photophysical and electrochemical properties of a series of novel cationic red iridium(III) complexes. We can tune the emission wavelengths in the range of red phosphorescence with high quantum efficiencies.

\section{Experimental Section}

Materials and synthesis. All reagents and solvents were commercially obtained from Sigma-Aldrich Chemicals or Acros Organics and used without further purification with an exception of tetrahydrofuran (THF), which was distilled from sodium/ benzophenone under nitrogen.

Synthesis of 2-phenylquinoxaline (pqx). 2-Chloroquinoxaline $(3.00 \mathrm{~g}, 18.2 \mathrm{mmol})$, phenylboronic acid $(2.44 \mathrm{~g}, 20.0$ $\mathrm{mmol})$ and tetrakis(triphenylphosphine)palladium $(0)(0.98 \mathrm{~g}$, $0.85 \mathrm{mmol}$ ) were dissolved to $50 \mathrm{~mL}$ of THF. After $5 \mathrm{~mL}$ of aqueous $4 \mathrm{M} \mathrm{K}_{2} \mathrm{CO}_{3}$ was delivered, reaction mixture was heated at $80{ }^{\circ} \mathrm{C}$ for $24 \mathrm{~h}$. The cooled crude mixture was poured onto water and extracted with dichloromethane $(50 \mathrm{~mL} \times 3$ times $)$, and dried over anhydrous magnesium sulfate. Silica column 
purification ( $n$-hexane: ethyl acetate $=5: 1)$ gave white solid. Yield: $84 \%$ (3.15 g). mp $77{ }^{\circ} \mathrm{C}$. ${ }^{1} \mathrm{H}$ NMR (300 MHz, $\left.\mathrm{CDCl}_{3}\right)$ $\delta 7.55(\mathrm{~m}, 3 \mathrm{H}), 7.73(\mathrm{~m}, 2 \mathrm{H}), 8.09(\mathrm{~m}, 4 \mathrm{H}), 9.34(\mathrm{~s}, 1 \mathrm{H})$.

Other ligands 2-(2,4-dimethoxyphenyl)quinoxaline (dmpqx) and 2-(2,4-difluorophenyl)quinoxaline (dfpqx) were prepared from 2-chloroquinoxaline with 2,4-dimethoxyphenylboronic acid and 2,4-difluorophenylboronic acid, respectively, by a similar procedure described for pqx ligand. The 2-benzo $[b]$ thiophen-2-yl-pyridine (btp) main ligand ${ }^{8}$ and $\mathrm{H}_{2}$ biim ancillary ligand $^{9}$ was synthesized in accordance with the published procedure.

dmpqx: Light yellow solid. Yield: $77 \%$ (3.75 g). mp $75^{\circ} \mathrm{C}$. ${ }^{1} \mathrm{H}$ NMR $\left(300 \mathrm{MHz}, \mathrm{CDCl}_{3}\right) \delta 3.90(\mathrm{~s}, 6 \mathrm{H}), 6.61(\mathrm{~s}, 1 \mathrm{H}), 6.69$ $(\mathrm{d}, 1 \mathrm{H}), 7.71(\mathrm{~m}, 1 \mathrm{H}), 7.91(\mathrm{~d}, 2 \mathrm{H}), 8.08(\mathrm{~m}, 2 \mathrm{H}), 9.35(\mathrm{~s}, 1 \mathrm{H})$.

dfpqx: White solid. Yield: $87 \%(3.80 \mathrm{~g}) . \mathrm{mp} 90{ }^{\circ} \mathrm{C} .{ }^{1} \mathrm{H}$ NMR $\left(300 \mathrm{MHz}, \mathrm{CDCl}_{3}\right) \delta 7.13(\mathrm{~m}, 1 \mathrm{H}), 7.17(\mathrm{~m}, 2 \mathrm{H}), 7.91(\mathrm{~m}, 2 \mathrm{H})$, $8.27(\mathrm{~m}, 2 \mathrm{H}), 9.45(\mathrm{~s}, 1 \mathrm{H})$.

Synthesis of $\left[(\mathbf{p q x})_{2} \mathbf{I r}(\boldsymbol{\mu}-\mathbf{C l})\right]_{2}$. A mixture of pqx (3.50 g, $17.01 \mathrm{mmol})$ and iridium chloride trihydrate $(2.00 \mathrm{~g}, 5.67 \mathrm{mmol})$, water $(10 \mathrm{~mL})$ and 2-ethoxyethanol $(30 \mathrm{~mL})$ was refluxed at $130{ }^{\circ} \mathrm{C}$ under nitrogen atmosphere for $24 \mathrm{~h}$. The resulting solution was concentrated at $60{ }^{\circ} \mathrm{C}$ under vacuum. The reaction mixture was allowed to cool to room temperature and treated with water $(30 \mathrm{~mL})$ to induce precipitation of a brown solid. The solid was filtered and washed with water, hexane and diethyl ether. The products were collected and dried in vacuum.

Other dimer complexes $\left[(\operatorname{dmpqx})_{2} \operatorname{Ir}(\mu-\mathrm{Cl})\right]_{2},\left[(\mathrm{dfpqx})_{2} \operatorname{Ir}(\mu-\right.$ $\mathrm{Cl})]_{2}$ and $\left[(\mathrm{btp})_{2} \operatorname{Ir}(\mu-\mathrm{Cl})\right]_{2}$ were prepared from iridium chloride trihydrate with dmpqx, dfpqx and btp, respectively, by a similar procedure described for the $\left[(\operatorname{pqx})_{2} \operatorname{Ir}(\mu-\mathrm{Cl})\right]_{2}$ complex.

Synthesis of $\left[(\mathbf{p q x})_{2} \operatorname{Ir}(\mathbf{b i i m})\right] \mathbf{C l}(\mathbf{1}) .\left[(\mathrm{pqx})_{2} \operatorname{Ir}(\mu-\mathrm{Cl})\right]_{2}(0.50 \mathrm{~g}$, $0.39 \mathrm{mmol})$, sodium carbonate $(0.414 \mathrm{~g}, 3.90 \mathrm{mmol})$ and 3 equivalent $\mathrm{H}_{2}$ biim $(0.16 \mathrm{~g} 1.17 \mathrm{mmol})$ were dissolved in $30 \mathrm{~mL}$ of 2-ethoxyethanol under nitrogen atmosphere. The mixture was heated to $130{ }^{\circ} \mathrm{C}$ and stirred for $20 \mathrm{~h}$. The resulting dark solution was concentrated under vacuum at $60{ }^{\circ} \mathrm{C}$ and residues were eluted through a silica column to afford $\left[(\mathrm{pqx})_{2} \operatorname{Ir}(\right.$ biim $\left.)\right] \mathrm{Cl}$ as a red solid. Yield: $36 \%(0.11 \mathrm{~g}) .{ }^{1} \mathrm{H} \mathrm{NMR}\left(300 \mathrm{MHz}, \mathrm{CDCl}_{3}\right) \delta$ $6.51(\mathrm{~s}, 2 \mathrm{H}), 6.59(\mathrm{~d}, 2 \mathrm{H}), 6.81(\mathrm{t}, 2 \mathrm{H}), 6.98(\mathrm{~s}, 2 \mathrm{H}), 7.13(\mathrm{q}, 4 \mathrm{H})$, 7.47 (d, 2H), 7.57 (m, 4H), 8.07 (q, 2H), 9.47 (s, 2H).

[(dmpqx) $\operatorname{Ir}$ (biim)]Cl (2): Dark red solid. Yield: $32 \%(0.12$ g). ${ }^{1} \mathrm{H}$ NMR $\left(300 \mathrm{MHz}, \mathrm{CDCl}_{3}\right) \delta 3.29(\mathrm{~s}, 6 \mathrm{H}), 4.06(\mathrm{~s}, 6 \mathrm{H})$, $5.75(\mathrm{~s}, 2 \mathrm{H}), 6.23(\mathrm{~s}, 2 \mathrm{H}), 6.64(\mathrm{~s}, 2 \mathrm{H}), 6.98(\mathrm{~s}, 1 \mathrm{H}), 7.08(\mathrm{t}$, 2H), $7.41(\mathrm{~m}, 4 \mathrm{H}), 7.71(\mathrm{~b}, 1 \mathrm{H}), 7.95(\mathrm{~m}, 2 \mathrm{H}), 7.92(\mathrm{~d}, 2 \mathrm{H})$, $10.12(\mathrm{~s}, 2 \mathrm{H})$.

[(dfpqx) $\mathbf{I r}$ (biim)]Cl (3): Orange-red solid. Yield: 40\%(0.10 g). ${ }^{1} \mathrm{H}$ NMR $\left(300 \mathrm{MHz}, \mathrm{CDCl}_{3}\right) \delta 6.02(\mathrm{~d}, 2 \mathrm{H}), 6.55(\mathrm{~m}, 2 \mathrm{H})$, $6.71(\mathrm{~m}, 1 \mathrm{H}), 6.98(\mathrm{~d}, 1 \mathrm{H}), 7.52(\mathrm{~s}, 1 \mathrm{H}), 7.96(\mathrm{~d}, 1 \mathrm{H}), 8.11(\mathrm{~d}$, 2H), 9.83 (d, 2H).

[(btp) $)_{2} \mathbf{I r}($ biim)]Cl (4): Yellow solid. Yield: $41 \%(0.12 \mathrm{~g})$. ${ }^{1} \mathrm{H}$ NMR $\left(300 \mathrm{MHz}, \mathrm{CDCl}_{3}\right) \delta 6.14(\mathrm{~d}, 2 \mathrm{H}), 6.41(\mathrm{~s}, 2 \mathrm{H}), 6.80$ $(\mathrm{m}, 4 \mathrm{H}), 7.05(\mathrm{~s}, 2 \mathrm{H}), 7.12(\mathrm{t}, 2 \mathrm{H}), 7.58(\mathrm{~d}, 2 \mathrm{H}), 7.66(\mathrm{~m}, 4 \mathrm{H})$, 7.69 (d, 2H).

Measurements. The ${ }^{1} \mathrm{H}$ NMR spectra were recorded on a Varian Mercury $300 \mathrm{MHz}$ instruments and chemical shifts were referenced to residual protiated solvent. The UV-visible spectra were recorded on a Jasco V-570 UV-vis spectrophotometer and photoluminescence (PL) spectra were recorded at room temperature with a Hitachi F-4500 fluorescence spectrophotometer in the range of $400 \sim 800 \mathrm{~nm}$. Quinine sulfate/1.0 N $\mathrm{H}_{2} \mathrm{SO}_{4}$ was used as a reference assuming a quantum yield of 0.56 with $360 \mathrm{~nm}$ excitation, to determine luminescence quantum yields of the studied compounds. Solution samples were degassed by three freeze pump-thaw cycles. The resulting luminescence was acquired by an intensified charge-coupled detector. Electrochemical measurements were performed with a Bioanalytical Systems CV-50 W electrochemical analyzer using three electrode cell assemblies. The electrochemical cell consists of a glassy carbon working electrode, platinum wire counter electrode and $\mathrm{Ag} / \mathrm{AgCl}$ reference electrode. The oxidation and reduction measurements were recorded in a dichloromethane solution containing tetra( $n$-butyl)ammonium tetrafluorophosphate as a supporting electrolyte at the scan rate of $50 \mathrm{mV} \mathrm{s}^{-1}$ under nitrogen condition. Each oxidation potential was calibrated with use of ferrocene as a reference. Concentration of iridium(III) complexes and supporting electrolyte were $10^{-3} \mathrm{M}$ and $10^{-1} \mathrm{M}$, respectively.

X-ray crystallography. X-ray intensity data were collected on a Bruker SMART APEX-II CCD diffractometer equipped with graphite monochromated Mo K $\alpha$ radiation. Initial unit cell parameters were obtained from SMART software. ${ }^{10}$ Data integration, correction for Lorentz and polarization effects and final cell refinement were performed by SAINTPLUS. ${ }^{11}$ An empirical absorption correction based on the multiple measurement of equivalent reflections was applied using SADABS program. ${ }^{12}$ Structure was obtained by a combination of the direct methods and difference Fourier syntheses and refined by fullmatrix least-squares on $\mathrm{F}^{2}$ using the SHELXTL. ${ }^{13}$ All non-hydrogen atoms were refined anisotropically. All hydrogen atoms were replaced in ideal positions and refined as riding atoms with relative isotropic displacement parameters.

\section{Results and Discussion}

Synthesis and structural characterization. The reaction of pqx and $\mathrm{IrCl}_{3} \cdot \mathrm{nH}_{2} \mathrm{O}$ in 2-ethoxyethanol afforded chloride-bridged dimer complex $\left[(\mathrm{pqx})_{2} \operatorname{Ir}(\mu-\mathrm{Cl})\right]_{2}$. Subsequently, the monomeric complex $\left[(\mathrm{pqx})_{2} \operatorname{Ir}(\text { biim })\right]^{+}(\mathbf{1})$ was obtained by the treatment of $\left[(\mathrm{pqx})_{2} \operatorname{Ir}(\mu-\mathrm{Cl})\right]_{2}$ dimer with $\mathrm{H}_{2}$ biim ligand in the presence of $\mathrm{Na}_{2} \mathrm{CO}_{3}$. Similarly, the $\left[(\operatorname{dmpqx})_{2} \operatorname{Ir}(\mu-\mathrm{Cl})\right]_{2},\left[(\operatorname{dfpqx})_{2} \operatorname{Ir}(\mu-\mathrm{Cl})\right]_{2}$, and $\left[(\mathrm{btp})_{2} \operatorname{Ir}(\mu-\mathrm{Cl})\right]_{2}$ dimers and their monomeric iridium(III) complexes $\left[(\mathrm{dmpqx})_{2} \operatorname{Ir}(\text { biim })\right]^{+}(\mathbf{2}),\left[(\mathrm{dfpqx})_{2} \operatorname{Ir}(\text { biim })\right]^{+}(\mathbf{3})$, and $\left[(\text { btp })_{2} \operatorname{Ir}(\text { biim })\right]^{+}(4)$ were synthesized for the purpose of subtle tuning of the emission wavelength. Scheme 1 outlines the synthetic protocol for red phosphorescent iridium(III) complexes. All iridium(III) complexes are soluble in chlorinated solvents. ${ }^{1} \mathrm{H}$ NMR spectral analyses are consistent with the proposed structures. The complex $\left[(\mathrm{pqx})_{2} \operatorname{Ir}(\right.$ biim $\left.)\right] \mathrm{Cl}$ (1) was further identified using single-crystal X-ray analysis to establish its threedimensional structure.

A single crystal of $\left[(\mathrm{pqx})_{2} \operatorname{Ir}(\right.$ biim $\left.)\right] \mathrm{Cl}(\mathbf{1})$ was grown by diffusion of hexane into concentrated dichloromethane solution, and its structure was unambiguously confirmed by X-ray crystallography. The molecular structure is given in Fig. 1. X-ray crystallographic data are in Table 1 and selected bond lengths and bond angles are summarized in Table 2. As depicted in 

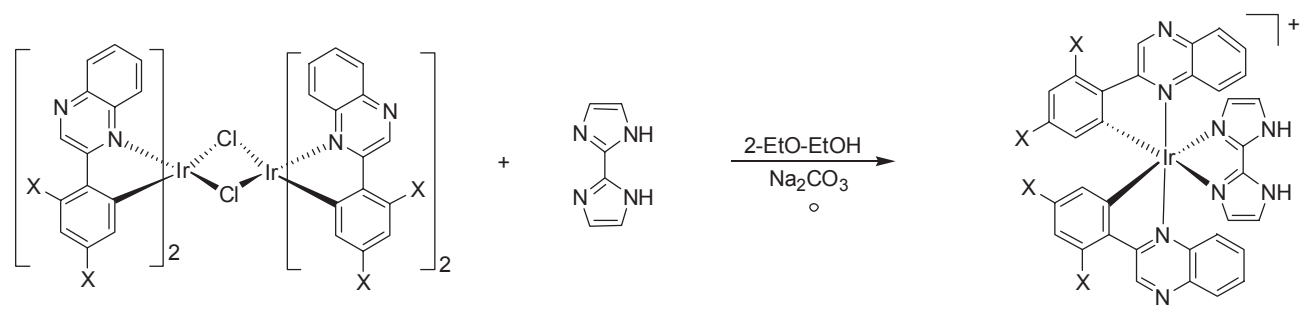

$1\left[(\text { pqx })_{2} \operatorname{lr}(\right.$ biim $\left.)\right]+; \quad X=\mathrm{H}$ $2\left[(\mathrm{dmpqx})_{2} \operatorname{Ir}(\mathrm{biim})\right]+; \mathrm{X}=\mathrm{OCH}_{3}$
$3\left[(\mathrm{dfpqx})_{2} \operatorname{lr}(\mathrm{biim})\right]+; \mathrm{X}=\mathrm{F}$
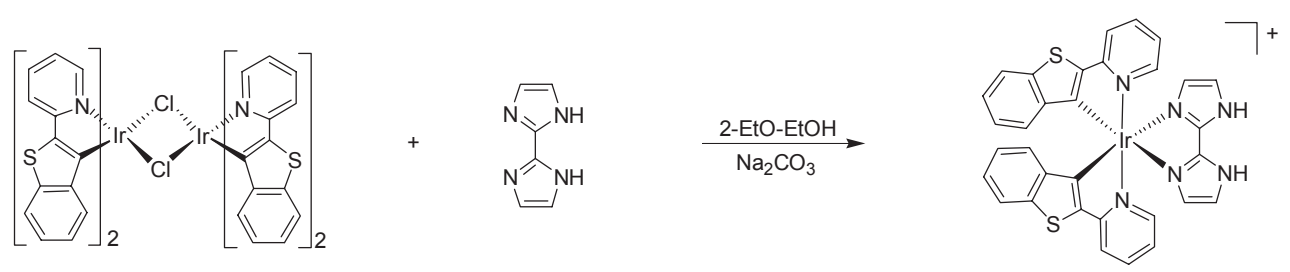

$4\left[(\text { btp })_{2} \operatorname{Ir}(\text { biim })\right]^{+}$

Scheme 1. Syntheses of iridium(III) complexes

Table 1. Crystallographic data of $\left[(\mathrm{pqx})_{2} \operatorname{Ir}(\right.$ biim $\left.)\right] \mathrm{Cl}$ (1)

\begin{tabular}{ll}
\hline Complex & {$\left[(\mathrm{pqx})_{2} \mathrm{Ir}(\mathrm{biim})\right] \mathrm{Cl}_{1} \mathrm{CH}_{2} \mathrm{Cl}_{2}$} \\
\hline Chemical formula & $\mathrm{C}_{35} \mathrm{H}_{26} \mathrm{~N}_{8} \mathrm{Cl}_{3} \mathrm{Ir}$ \\
Formula weight $(\mathrm{amu})$ & 857.19 \\
Crystal description & red \\
Crystal size $(\mathrm{mm})$ & $0.06 \times 0.05 \times 0.05$ \\
Crystal system & Triclinic \\
Space group & $\mathrm{P}-1$ \\
$\mathrm{~T}(\mathrm{~K})$ & $295(2)$ \\
Wavelength $(\AA)$ & 0.71073 \\
$a(\AA) \& \alpha\left(^{\circ}\right)$ & $9.1471(18) \& 89.54(3)$ \\
$b(\AA) \& \beta\left(^{\circ}\right)$ & $10.473(2) \& 83.92(3)$ \\
$c(\AA) \& \gamma\left({ }^{\circ}\right)$ & $19.027(4) \& 66.78(3)$ \\
Volume $(\AA) \& Z$ & $1664.5(7) \& 2$ \\
$D_{\text {calc }}\left(\mathrm{Mg} / \mathrm{m}^{3}\right)$ & 1.710 \\
$\mu\left(\right.$ mm $\left.{ }^{-1}\right)$ & 4.291 \\
$\theta$ Range $\left({ }^{\circ}\right)$ & 1.08 to 26.00 \\
$\left.T_{\text {max }} \& T_{\text {min }}\right)$ & $0.0805 \& 0.770$ \\
Index ranges & $-11 \leq h \leq 11 ;-12 \leq k \leq 12 ;-23 \leq l \leq 23$ \\
Reflections collected/unique & $29886 / 6500[\mathrm{R}(\mathrm{int})=0.0519]$ \\
Final $R$ indices $[I>2 \sigma(I)]$ & $R_{1}=0.0295, w R_{2}=0.0537$ \\
$\mathrm{R}$ indices $($ all data) & $R_{1}=0.0404, w R_{2}=0.0600$ \\
Data/Restraints/parameters & $6500 / 0 / 451$ \\
Goodness-of-fit on $\mathrm{F}^{2}$ & 1.023 \\
Largest diff. peak and hole $\left(\mathrm{e} \AA^{-3}\right)$ & $0.614 \&-0.598$ \\
\hline
\end{tabular}

Fig. 1, complex 1 reveals a distorted octahedral geometry around iridium(III) ion, consisting of two cyclometalated pqx ligands and a bidentate biimidazole ligand in which biimidazole retains its two N-H protons, and $\mathrm{N}-\mathrm{H} \cdots \mathrm{Cl}$ hydrogen bond with the counter anion creates ion pairs. The $\mathrm{N}-\mathrm{H}$ groups of biimidazole usually form strong hydrogen bonds in crystals. ${ }^{14}$ The $\mathrm{N} \cdots \mathrm{Cl}$ distances $(2.99 \AA)$ are on the short side of the accepted range $(2.91 \sim 3.53 \AA)^{15}$ and the $\mathrm{N}-\mathrm{H} \cdots \mathrm{Cl}$ angles $\left(158.93^{\circ}\right)$ are close to linearity. The $\mathrm{H}_{2}$ biim arrangement is planar. The bite angles at iridium(III) metal ion are $79.88(17)$ and $80.50(16)^{\circ}$ for the cyclometalating ligands and $75.03(14)^{\circ}$ for Ir-biimidazole which is typical for transition metal biimidazole complexes. ${ }^{16}$ The elongated $\mathrm{Ir}-\mathrm{N}$ bonds in $\left[(\mathrm{pqx})_{2} \operatorname{Ir}(\text { biim })\right]^{+}$are the result of the weaker basicity of quinoxaline in comparison with that of quinoline and pyridine. ${ }^{17}$ The pqx ligands adopt a mutual eclipse configuration with their coordinated $\mathrm{N}(1)$ and $\mathrm{N}(17)$ atoms and $\mathrm{C}(8)$ and $\mathrm{C}(24)$ atoms being in a trans and cis orientation, respectively, whereas the $\mathrm{H}_{2}$ biim is located at an unique position opposite to the carbon atoms of the pqx ligands. This ligand arrangement is similar to those of the parent 2-phenylpyridine 
Table 2. Selected bond lengths $(\AA)$ and angles $\left({ }^{\circ}\right)$ of $\left[(\operatorname{pqx})_{2} \operatorname{Ir}(\operatorname{biim})\right] C l$ (1)

\begin{tabular}{cccc}
\hline \multicolumn{2}{c}{ Bond distances $(\AA)$} & \multicolumn{2}{c}{ Bond angles $\left({ }^{\circ}\right)$} \\
\hline Ir-C8 & $1.980(4)$ & C8-Ir-C24 & $89.76(16)$ \\
Ir-C24 & $1.997(4)$ & C8-Ir-N1 & $80.50(16)$ \\
Ir-N17 & $2.100(4)$ & C24-Ir-N1 & $94.43(16)$ \\
Ir-N1 & $2.069(3)$ & C8-Ir-N17 & $96.30(16)$ \\
Ir-N42 & $2.159(4)$ & C24-Ir-N17 & $79.88(17)$ \\
Ir-N33 & $2.196(3)$ & N1-Ir-N17 & $173.53(14)$ \\
& & C8-Ir-N42 & $93.44(16)$ \\
& & C24-Ir-N42 & $175.88(15)$ \\
& & N1-Ir-N42 & $83.56(13)$ \\
& & N17-Ir-N42 & $102.31(14)$ \\
& & C8-Ir-N33 & $167.53(15)$ \\
& & C24-Ir-N33 & $101.99(14)$ \\
& & N1-Ir-N33 & $102.50(13)$ \\
& & N17-Ir-N33 & $81.83(13)$ \\
& & N42-Ir-N33 & $75.03(14)$ \\
\hline
\end{tabular}

ligands in chloride-bridged dimer complex $\left[(\text { ppy })_{2} \operatorname{Ir}(\mu-\mathrm{Cl})\right]_{2}{ }^{18}$ and diketonate complexes (ppy) ${ }_{2} \operatorname{Ir}(\text { acac })^{1,19}$ suggesting that the $\mathrm{H}_{2}$ biim ligand in our case is attached to the metal via a simple replacement of both chloride ligands. The bond angles in the iridium octahedron vary from $75.03(14)$ to $102.50(13)^{\circ}$ and from $167.53(15)$ to $175.88(15)^{\circ}$. The Ir-C distances are shorter than the Ir-N bond lengths. This result implies that a stronger trans influence of the phenyl ring in comparison to the pyridyl groups shows a trans $N-N^{\prime}$ configuration. The solvent molecule located in crystal lattice as a free molecule. In the crystal packing, $\left[(\mathrm{pqx})_{2} \operatorname{Ir}(\text { biim })\right]^{+}$displays shorter intermolecular distances of $3.65 \AA$ which is typical of aromatic-aromatic face-to-face $\pi-\pi$ stacking. Recently it was reported that intermolecular $\pi-\pi$ interactions have a direct influence on luminescent properties. ${ }^{20}$ The influence of this intermolecular interaction on the luminescence of iridium(III) complexes in this work will be discussed later.

Photophysical properties. The UV-visible and photoluminescence (PL) spectra of iridium(III) complexes (1-4) are shown in Fig. 2. Table 3 lists the photophysical properties of the complexes. All measurements were made in ambient-temperature in dichloromethane solution. All the complexes display strong absorption bands between 280 and $285 \mathrm{~nm}$ that can be attributed to the $\pi-\pi^{*}$ ligand-centered transitions. In addition, spin-allowed metal-to-ligand charge transfer ( ${ }^{1}$ MLCT) absorption is clearly distinguished in the region of $350 \sim 460 \mathrm{~nm}^{21}$ On the other hand, ${ }^{3} \mathrm{MLCT}$ transitions appear as a lower energy absorption shoulder in the region $420 \sim 490 \mathrm{~nm}$.

Complexes (1-4) exhibited a broad spectral emission in wavelength region from $580 \sim 620 \mathrm{~nm}$ in $\mathrm{CH}_{2} \mathrm{Cl}_{2}$, and showed high phosphorescence quantum efficiencies of $0.58 \sim 0.78$. In addition, photoluminescence spectra of these complexes in solid film were similar to those in $\mathrm{CH}_{2} \mathrm{Cl}_{2}$ solution. The emission maximum can be effectively tuned by varying the nature of substituent in the cyclometalated ligands. Ge, G. et al. ${ }^{22}$ reported that the emission wavelength was tuned in the heterocyclic portion by replacement of one $\mathrm{CH}$ group by a nitrogen atom at the pyridyl fragment. In case of our iridium(III) complexes,
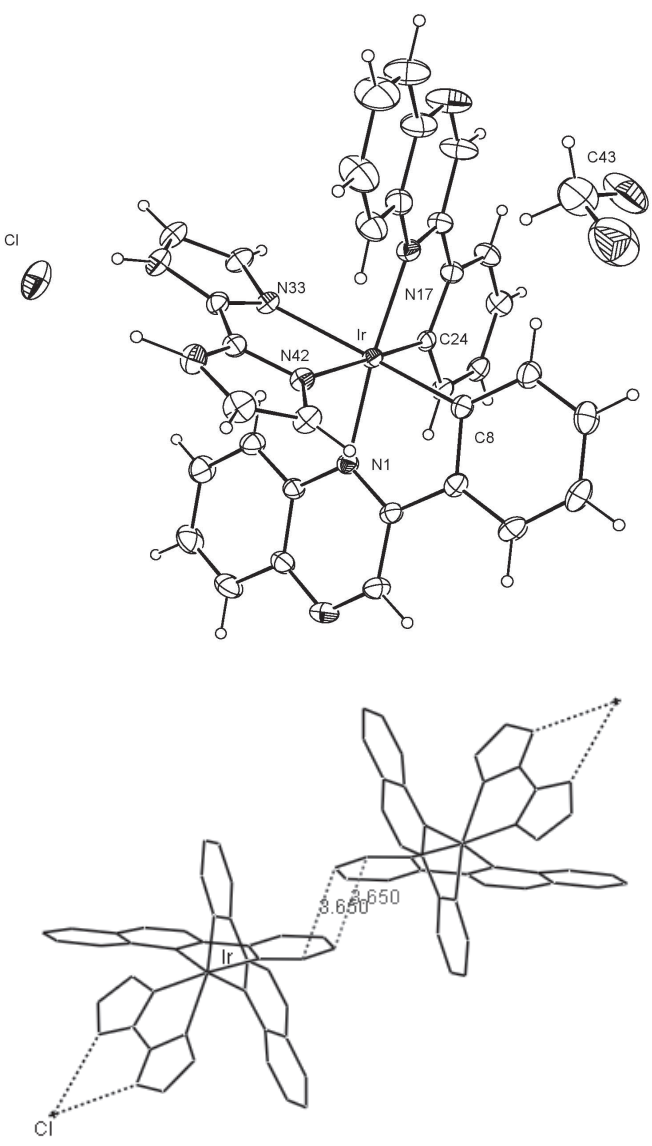

Figure 1. The molecular structure of $\left[(\mathrm{pqx})_{2} \operatorname{Ir}(\right.$ biim $\left.)\right] \mathrm{Cl}$ (1) (top), showing the atom-numbering scheme with $30 \%$ probability ellipsoides. Crystal packing diagram (bottom) between two adjacent molecules showing the $\pi-\pi$ stacking interaction.

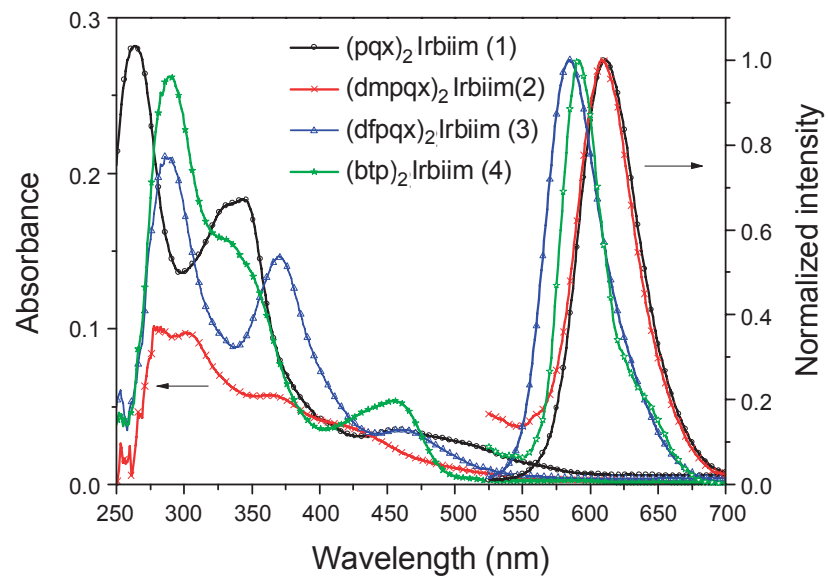

Figure 2. Absorption and normalized emission spectra of complexes (1-4) in $\mathrm{CH}_{2} \mathrm{Cl}_{2}$ at room temperature.

further attachment of extra aromatic hexagon into ligand framework, for example, using quinoxaline to replace the hypothetical pyrazine fragment gave a shift of the emission wavelengths to red. In comparison of $\mathbf{1}$ with $\mathbf{3}$ bearing the 2,4-difluorophenyl group reveals about $30 \mathrm{~nm}$ hypsochromic shift in the emission peak and can qualitatively be rationalized by a decrease of $\pi^{*}$ 
Table 3. Photophysical and electrochemical data of iridium(III) complexes 1-4

\begin{tabular}{|c|c|c|c|c|c|c|}
\hline \multirow{2}{*}{ Complexes } & \multirow{2}{*}{$\begin{array}{l}\text { Absorption } \lambda(\mathrm{nm}) \\
\left(\varepsilon, \times 10^{3} \mathrm{M}^{-1} \mathrm{~cm}^{-1}\right)^{a}\end{array}$} & $\lambda_{\mathrm{em}}(\mathrm{nm})$ & \multirow{2}{*}{$\Phi^{c}$} & \multirow{2}{*}{$\mathrm{E}_{\mathrm{ox}}(\mathrm{V})$} & \multirow{2}{*}{$\mathrm{E}_{\text {red }}(\mathrm{V})$} & \multirow{2}{*}{$\mathrm{E}_{\text {gap }}(\mathrm{eV})$} \\
\hline & & ${ }^{a} \mathrm{RT} / \mathrm{film}{ }^{b}$ & & & & \\
\hline$\left[(\mathrm{pqx})_{2} \operatorname{Ir}(\operatorname{biim})\right] \mathrm{Cl}(\mathbf{1})$ & $288(47.1) ; 355$ (30.0); 371 (31.7); 484 (5.8) & $618 / 616$ & 0.58 & 1.60 & $-1.15 ;-1.34$ & 2.01 \\
\hline$\left[(\operatorname{dmpqx})_{2} \operatorname{Ir}(\right.$ biim $\left.)\right] \mathrm{Cl}(\mathbf{2})$ & $288(11.8) ; 303$ (12.9); 364 (7.6); 425 (4.6) & $614 / 607$ & 0.61 & 1.43 & $-1.13 ;-1.45$ & 2.24 \\
\hline$\left[(\operatorname{dfpqx})_{2} \operatorname{Ir}(\right.$ biim $\left.)\right] \mathrm{Cl}(3)$ & $288(35.2) ; 370(24.6) ; 463(5.8)$ & $588 / 587$ & 0.78 & 1.89 & $-1.16 ;-1.40$ & 2.09 \\
\hline$\left[(\text { btp })_{2} \operatorname{Ir}(\right.$ biim $\left.)\right] \mathrm{Cl}(4)$ & 289 (42.3); 332 (24.3); 457 (8.7); 472 (4.8) & $592 / 592$ & 0.63 & 1.24 & -1.80 & 2.50 \\
\hline
\end{tabular}

${ }^{a}$ All data were monitored in $1 \times 10^{-5} \mathrm{M}$ solution of iridium(III) complexes in $\mathrm{CH}_{2} \mathrm{Cl}_{2} .{ }^{b}$ PMMA film doped with $5.0 \mathrm{wt} \%$ of $\operatorname{Ir}(\mathrm{III})$ complexes. ${ }^{c}$ Ir(ppy) $(0.40)$ was used as an external reference. ${ }^{d} \mathrm{E}_{1 / 2}$ refers to $\left[\left(\mathrm{E}_{\mathrm{pa}}+\mathrm{E}_{\mathrm{pc}}\right) / 2\right]$ where $\mathrm{E}_{\mathrm{pa}}$ and $\mathrm{E}_{\mathrm{pc}}$ are the anodic and cathodic peak potentials referenced to the $\mathrm{Fc} / \mathrm{Fc}^{+}$couple and the oxidation and reduction experiments were conducted in $\mathrm{CH}_{2} \mathrm{Cl}_{2}$ solution.

MO energy level due to stronger electron withdrawing character of the fluorine atom at ortho- and para-positions. ${ }^{23}$ Furthermore, the $\pi-\pi$ stacking interaction between phenyl rings with the shortest separation distance of about $3.65 \AA$ and the hydrogen bonds between the biimidazole hydrogens and chloride ions in crystal caused a red-shift in complex $\mathbf{1}$. In complex 2 , the electron releasing substituent $-\mathrm{OCH}_{3}$ group did not show much impact in emission wavelength relative to $\mathbf{1}$, showing a little blue shift. Similar phenomena were also observed in iridium(III) complexes containing substituted quinoline, no matter what the substitutes in 2-phenyl ring of quinoline unit were electron withdrawing or releasing group. ${ }^{24} \mathrm{We}$ assume that an increase in the steric hindrance via the introduction of a bulky $-\mathrm{OCH}_{3}$ groups in complex 2 reduces the intermolecular interaction resulting in a blue-shift in emission energy of complex 2 relative to complex 1. In a similar complex, $(\mathrm{dmpqx})_{2} \operatorname{Ir}(\mathrm{mprz})(\mathrm{mprz}=$ 3 -methylpyrazine carboxylate) does not exhibit $\pi-\pi$ stacking in the crystal packing ${ }^{25}$ because the sterically hindered methoxy group in the phosphor molecule leads to a minimum bimolecular interaction.

Electrochemical properties. The electrochemical behaviors were examined in $\mathrm{CH}_{2} \mathrm{Cl}_{2}$ solution using cyclic voltammetry, and the electrochemical data are reported relative to a ferrocenium/ferrocene redox couple, as shown in Table 3 . The complexes (1-3) underwent an irreversible oxidation potential in the range of 1.40 to $1.90 \mathrm{~V}$ and double quasi-reversible reduction waves from $\mathrm{E}_{\mathrm{pc}}^{1}=-1.13$ to $-1.15 \mathrm{~V}$ and from $\mathrm{E}_{\mathrm{pc}}^{2}=-1.34$ to $-1.45 \mathrm{~V}$. As revealed previously by electrochemistry and theoretical calculations ${ }^{22,26}$ of cyclometalated iridium(III) complexes, oxidation processes are linked to metal-centered orbitals with a contribution from the phenyl part of cyclometalated fragments, which usually lead to a loss of electrochemical reversibility. On the other hand, reduction is generally considered to occur from an orbital centered mainly on the Ir-biim fragment with a contribution of electron accepting heterocyclic portion of the cyclometalated ligands. Consistent with this conclusion, our complexes have similar LUMO energy levels due to the same biim and pyridyl based frame, which makes the reduction potential of these complexes stay in a narrow range. Their HOMO energy levels systematically change with the structures of $\mathrm{C}^{\wedge} \mathrm{N}$ ligands. The oxidation potential of complex $\mathbf{3}$ with electron withdrawing fluorine atoms on the 2,4-position of phenyl ring is $1.89 \mathrm{~V}$, which was shifted cathodically by $0.29 \mathrm{~V}$ compared to the complex $\mathbf{1}$, while complex $\mathbf{2}$ containing electron releasing $-\mathrm{OCH}_{3}$ groups on the 2,4-position of phenyl ring had lower value of $0.46 \mathrm{~V}$. It was found that an incorporation of electron withdrawing fluorine atoms on phenyl ring led to a marked increase in oxidation potential while the electron releasing $-\mathrm{OCH}_{3}$ group on phenyl ring decreased the oxidation potential. The $\left[(\mathrm{btp})_{2} \operatorname{Ir}(\mathrm{biim})\right]^{+}$complex (4) underwent a reversible oxidation potential at about $1.24 \mathrm{~V}$ and irreversible reduction waves at $-1.80 \mathrm{~V}$. The electron deficient $\mathrm{N}$ atom in biim ancillary ligand made the iridium(III) more difficult to oxidate in $\left[(\mathrm{btp})_{2} \operatorname{Ir}(\mathrm{biim})\right]^{+}$complex $(1.24 \mathrm{~V})$ than in (btp $)_{2} \operatorname{Ir}(\mathrm{acac})$ $(0.72 \mathrm{~V})$. These results clearly demonstrate that the introduction of electron-withdrawing groups on phenyl ring is effective for lowering the HOMO energy level to show a large blue shift, and electron releasing group raises the HOMO energy level in phosphorescence of iridium(III) complexes.

\section{Conclusion}

We synthesized four heteroleptic iridium(III) complexes (1-4) and studied their photophysical and electrochemical properties. These complexes incorporated the utilization of two subsitituted cyclometalated ligands with extended $\pi$ system with fused heteroaromatic rings and one chromophoric ancillary ligand to counterbalance the energy gap suited to the saturated red emission. Depending on the substitutes of cyclometalated ligands, these complexes were found to emit from red-orange to deep red phosphorescence arose dominantly from the ${ }^{3}$ MLCT excited state. These complexes exhibit high emission quantum yields that are suitable for serving as red-emitting materials for OLEDs applications. We have successfully elucidated the color tuning of heteroleptic iridium(III) complexes via relative energy level control of the main and ancillary ligands.

Supplementary Materials. Crystallographic data for the structural analysis have been deposited with the Cambridge Crystallographic Data Centre, CCDC Nos. 770520 for [(pqx) $)_{2}$ Ir (biim) $\mathrm{Cl}$ (1). Copies of this information may be obtained free of charge from The Director, CCDC, 12 Union Road, Cambridge, CB2 1EZ, UK (fax: +44-223-336-033; e-mail: deposit@) ccdc.cam.ac.uk or www: http://www.ccdc.cam.ac.uk).

Acknowledgments. This work was supported by National Research Foundation of Korea Grant funded by the Korean Government (No. 2010-0017080). X-ray data were collected at the center for Research Facilities in Chungnam National University. 


\section{References}

1. (a) Lamansky, S.; Djurovich, P.; Murphy, D.; Abdel-Razzaq, F.; Lee, H. E.; Adachi, C.; Burrows, P. E.; Forrest, S. R.; Thompson, M. E. J. Am. Chem. Soc. 2001, 123, 4304. (b) Thomas, K. R.; Velusamy, M.; Lin, J. T.; Chien, C. H.; Tao, Y. T.; Wen, Y. S.; Hu, Y. H.; Chou, P. T. Inorg. Chem. 2005, 44, 5677. (c) Lu, W.; Mi, B. X.; Chan, M. C. W.; Hui, Z.; Che, C. M.; Zhu, N.; Lee, S. T. J. Am. Chem. Soc. 2004, 126, 4958. (d) Kim, D.-H.; Hong, C.-K.; Lee, P. H.; Kang, Y. Bull. Korean Chem. Soc. 2008, 29, 2270. (e) Ma, A.-F.; Seo, H.-J.; Jin, S.-H.; Yoon, Y. C.; Hyun, M.-H.; Kim, Y.-I. Bull. Korean Chem. Soc. 2009, 30, 2754. (f) Seo, H.-J.; Yoo, K.-M.; Song, M.; Park, J. S.; Jin, S.-H.; Kim, Y.-I.; Kim, J.-J. Org. Electr. 2010, 11,564 .

2. (a) Marco, D. G.; Lanza, M.; Mamo, A.; Stefio, I.; Pietro, D. C.; Romeo, G.; Campagna, S. Anal. Chem. 1998, 70, 5019. (b) Goodall, W.; Williams, J. A. G. J. Chem. Soc., Dalton Trans. 2000, 2893.

3. (a) Lo, K. K. W.; Chan, J. S. W.; Lui, L. H.; Chung, C. K. Organometallics 2004, 23, 3108. (b) Lo, K. K. W.; Chung, C. K.; Lee, T. K. M.; Lui, L. H.; Tsang, K. H. K.; Zhu, N. Inorg. Chem. 2003, 42,6886 .

4. (a) Nazeeruddin, M. K.; Wegh, R. T.; Zhou, Z.; Klein, C.; Wang, Q.; De Angelis, F.; Fantacci, S.; Grätzel, M. Inorg. Chem. 2006, 45, 9245. (b) Slinker, J.; Bernards, D.; Houston, P. L.; Abruña, H. D.; Bernhard, S.; Malliaras, G. G. Chem. Commun. 2003, 2392.

5. (a) Handy, E. S.; Pal, A. J.; Rubner, M. F. J. Am. Chem. Soc. 1999, 121, 3525. (b) Gao, F. G.; Bard, A. J. J. Am. Chem. Soc. 2000, 122, 7426. (b) Goldsmith, J. I.; Hudson, W. R.; Lowry, M. S.; Anderson, T. H.; Bernhard, S. J. Am. Chem. Soc. 2005, 127, 7502. (c) Bolink, H. J.; Cappelli, L.; Coronado, E.; Grätzel, M.; Ortí, E.; Costa, R. D.; Viruela, P. M.; Nazeeruddin, M. J. Am. Chem. Soc. 2006, 128, 14787.

6. Freys, J. C.; Bernardinellib, G.; Wenger, O. S. Chem. Commun. 2008, 4267.

7. Grushin, V. V.; Herron, N.; LeCloux, D. D.; Marshall, W. J.; Petrov, V. A.; Wang, Y. Chem. Commun. 2001, 1494.

8. Frampton, M. J.; Namdas, E. B.; Lo, S.-C.; Burn, P. L.; Samuel, I. D. W. J. Mater. Chem. 2004, 14, 2881.

9. Xiao, J. C.; Shreeve, J. M. J. Org. Chem. 2005, 70, 3072.

10. SMART V5.05 Software for CCD Detector System; Bruker Anal- ytical X-ray Systems, madison, WI, 1998.

11. SAINTPLUS, V5.00 Software for the CCD Detector System; Bruker Analytical X-ray System, Inc.: Madison, WI, 1998.

12. SADABS. Program for absorption correction using SMART CCD based on the method of Blessing, R. H. Acta Crystallogr. 1995, A51, 33 .

13. Sheldrick, G. M. SHELXTL, V6.1; Bruker Analytical X-ray systems, Inc.: madison, WI, 1997.

14. Fortin, S.; Fabre, P.-L.; Dartiguenave, M.; Beauchamp, A. L. J. Chem. Soc., Dalton Trans. 2001, 3520.

15. Stout, G. H.; Jensen, L. H. X-Ray Structure Determination, A Practical Guide; The Macmillan Company: London, 1968.

16. (a) Jeffrey, G. A.; Maluszynska, H.; Mitra, J. Int. J. Biol. Macromol. 1985, 7, 336. (b) Rasmussen, P. G.; Bailey, O. H.; Bayón, J. C.; Butler, W. M. Inorg. Chem. 1984, 23, 338.

17. Zhao, Q.; Liu, S.; Shi, M.; Wang, C.; Yu, M.; Li, L.; Li, F.; Yi, T.; Huang, C. Inorg. Chem. 2006, 45, 6152.

18. Graces, F. O.; King, K. A.; Watts, R. J. Inorg. Chem. 1988, 27, 3464.

19. Lamansky, S.; Djurovich, P.; Murphy, D.; Abdel-Razzaq, F.; Kwong, R.; Tsyba, I.; Bortz, M.; Mui, B.; Bau, R.; Thompson, M. E. Inorg. Chem. 2001, 40, 1704.

20. (a) Xie, H. Z.; Liu, M. W.; Wang, O. Y.; Zhang, X. H.; Lee, C. S.; Hung, L. S.; Lee, S. T.; Teng, P. F.; Kwong, H. L.; Zheng, H.; Che, C. M. Adv. Mater. 2001, 13, 1245. (b) Jung, S.; Kang, Y.; Kim, H.; Kim, Y.; Lee, C.; Kim, J.; Lee, S.; Kwon, S. Eur. J. Inorg. Chem. 2004, 3415 .

21. Wilde, A. P.; King, K. A.; Watts, R. J. J. Phys. Chem. 1991, 95, 629.

22. Ge, G.; Zhang, G.; Guo, H.; Chuai, Y.; Zou, D. Inorg. Chim. Acta 2009, 362, 2231 .

23. Hwang, F.-M.; Chen, H.-Y.; Chen, P.-S.; Liu, C.-S.; Chi, Y.; Shu, C.-F.; Wu, F.-I.; Chou, P.-T.; Peng, S.-M.; Lee, G.-H. Inorg. Chem. 2005, 44, 1344.

24. Ding, J.; Gao, J.; Fu, Q.; Cheng, Y.; Ma, D.; Wang, L. Syn. Met. 2005, 155, 539.

25. Unpublished results; CCDC No. 671925.

26. (a) Dragonetti, C.; Falciola, L.; Mussini, P.; Righetto, S.; Roberto, D.; Ugo, R.; Valore, A.; Angelis, D. F.; Fantacci, S.; Sgamellotti, A.; Ramon, M.; Muccini, M. Inorg. Chem. 2007, 46, 8533. (b) Lowry, M. S.; Goldsmith, J. I.; Slinker, J. D.; Rohl, R.; Pascal, R. A., Jr.; Malliaras, G. G.; Bernhard, S. Chem. Mater. 2005, 17, 5712. 